\title{
The Impact of Hate Speech on Nigeria Economy
}

\author{
Ukauwa, Ezechimerem Ephraim \\ Department of Economics \\ Abuja University \\ Bilal Celik \\ Department of Economics \\ Nile University of Nigeria \\ Gylych Jelilov \\ Department of Economics \\ Nile University of Nigeria \\ Natalia Olali \\ Department of Mathematics \\ University of Niger Delta
}

\begin{abstract}
This study sets out to investigate the Impact of Hate Speech on Nigeria Economy. To do this, the survey population is made up of bank officials who notice the capital flight before it trickles down to the public, and the politicians who have been accused of patronizing high dosage of hate speech. Taro Yamane formula came handy as sample questionnaires were distributed that covered the targeted population from which the primary data were extracted for analysis. Information from other literatures was helpful which include textbooks, social media, bulletins and journals. The research used survey and descriptive data also using simple percentages of figures extracted from the tables for interpretation. There are overwhelming responses and findings to the fact that hate speech impact negatively on Nigeria and aggravate capital flight while socio-political effect in Nigeria is also damming. The outcome of the research includes the recommendations that there should be citizens' orientation on rights and privileges, patriotism by all to forestall endangering the system and political will to bring offenders to book as a deterrent to others who may want to toe the same way.
\end{abstract}

Keywords: Hate speech, Nigeria Economy, Patriotism, Political will

\section{Introduction}

Hate speech is understood to be "all communications (whether verbal, written, symbolic) that insults a racial, ethnic and political group, whether by suggesting that they are inferior in some respect or by indicating that they are despised or not welcome for any other reasons" (Neisser, 1994). Also, hate speech is referred to as "war waged on others by means of words"Kayambazinthu\&Moyo, 2002). Mostonline communication was regarded as normal however, recently, occasioned by political mudslinging, has turnedthe arena into hate speech. As regards motivation for hate speech, it has been pointed out by many scholars that several conditions which discrimination, lack of accommodation for market place political ideologies, lack of accountability and harvest of ideas from social media has continuously fuelled hate speech. Both online and print Media were expected to uplift man's existence, but it has been found to be the undoing of today's civilization creating hate and racism(Spiegel, 1999; Nemes, 2002 andWitschge, 2008). The ills that are found in the use of internet have remained in the domain of mindset of the users (Witschge, 2008). Leets (2002) in his own contribution states that hate speech effect is quite monumental such that among other effects, it also humiliates, creates distress, distrust and economic downturn.

There are some rights that are enshrined in international and local laws that emphasize on human rights and dignity. These are known as fundamental rights. These rights are universally acclaimed and protected by the instruments of law of various United Nations member states. The populations in these states enjoy these rights unfettered. The right to freedom of speech, being one of these rights is also protected under the Universal Declaration of Human Rights and other various regional Instruments and Conventions on human rights, is also domesticated in the African Charter on Human and Peoples Rights, 1986. States are enjoined to protect these rights of their citizens using the agencies of the state. 
As the states are obliged to protect these rights, violation of other peoples' rights by individuals while exercising these rights by individuals, would be met by stiff consequences on individuals that do so. Hence, there are restrictions and exemptions enshrined in different laws to address these violations. These provisions have provided extent of freedom of speech allowable as long as the other person's right is not trampled. The constitutional provision, being the grundnum, has made such violations justiciable which the court to adjudicate and balance conflicting interests between freedom of speech and protection of reputation ensuring that all rights are enjoyed within the ambit of the Nigeria Constitution and extant laws.

Consequently, the aberration inflicted on freedom of speech while perpetrating hate speech has met stone wall since redress could be sought by one who is maligned under the guise of freedom of speech through both the Nigerian Constitution and the International Instruments. Section 39(3) of the 1999 Constitution of Nigeria as amended, provides how justifiable means through which right to freedom of speech could be curtailed even in a democratic setting. Hate speech can be demonstrated in different guises such as in speech, gesture, conduct, writing ordisplay and can incite people to violence action (Coleman, 1986).Violation of individual dignity, stress and distress, humiliation, fear and multiple embarrassment flow from unrestricted freedom of speech which are dangerous to human development Leets, 2002;Nemes, 2002; Nielsen, 2002 and Parekh, 2006).

Hate speech also elucidates pain, distress, fear, embarrassment and isolation to individuals such that when it is directed a group of people, fans the embers of inequality, isolation and creates feeling of fear and discourages them from participating in the community and expressing their opinions. This reinforces our previous argument that hate speech degrades, humiliates and makes the victim aggressive and dangerous as it has been observed in different quarters of the Nigerian polity.

An anomalous entity called Nigeria, as emphasized by Ekanola(2006) has made hate speech to thrive as each ethnic group could be identified physically and attacked at random which can trigger off distortion of the economy, brain drain and move investments away from the troubled zone.

In recent time, in the democratic experiment of Nigeria, the causes of hate speech bedeviling Nigeria range from psychological and tribal definition of causes to the bizarre such as tribal mark which, together with its threat to national unity and life security remains an issue of great concern in the Nigeria polity and economy.

The paper is organized as follows: Section One is the Introduction while Section Two is the Literature Review; Section Three is the brief Research Methodology, Sections Four is Data Analysis and Interpretation of Result while Section Five is the Summary, Conclusions and Recommendations.

\section{Section Two: Literature Review and Theoretical Framework}

\subsection{Concept of Hate Speech and Scope of Freedom of Speech Expression}

Hate Speech came into arena of discuss as the political activity in Nigeria started progressing to the crescendo. It became an instrument in the hands of the politician who had no tangible to present to the populace to warrant them either to be voted back to power or lack of any superior argument to unseat the present occupant of the office. Hence, bereft of any good reason to seek for political office, resorted to hate speech to whip up sentiment and violence in election related issues.

Freedom of expression is important to human race as all tend to pass information from one to another. This has continued to make human race to exploit every means of communication which range from body language, verbal speech and to print, television and most recently, social media. All these are to promote harmony and societal development. Management of diversities in any society such as population, culture, politics and religion, should be asset to any society that understands it instead of using it for anarchy, controversy and bloodshed.The constant muzzling of the populace into silence as the ruling class is unsettled by the loose use of freedom of speechDrawing from Article 9 of the African Charter on Human and Peoples Rights and Article 19 of the International Covenant on Civil and Political Rightsand Article 13 of the American Convention of Human Rights, free speech is necessary for intellectual and social progress attainment..

It is an unalienable right of every individual to hold opinion without let or any encumbrances. One is also at liberty to discuss issues openly and impart ideas. Societies, including Nigeria are built on unhindered opinions which are a strong pillar on which democratic tenets rest. Both free speech and a free press are necessary instruments for meaningful democratic governance. Also, various International Instruments on human rights and fundamental freedom has three constituent elements namelythe freedom to a) hold opinions, b) receive ideas and information and c) impart ideas and information. 
It is obligatory and incumbent on all users this freedom to note the reliefs available to others not to infringing on their rights and reputations. Hence, the right to freedom of expression is not absolute, but qualified. This is why hate speech syndrome recently discovered in Nigeria lexicon as namecalling and whipping up sentiments became an instrument in the hands of the outperforming politicians to the admiration and recruitment of common voters into the fray for the politicians' personal gain, must have its repercussion on its users and beneficiaries.However, the law courts ensures and maintain respect of the rights or reputation of others and protection of national security and public order, else, anarchy will ensue.

\subsection{Theoretical Framework and Legal Instrument against Hate Speech}

Having understood that hate speech is any speech that is harmful which could be expressed in gesture, conduct, writing or display which is aimed to incite to violence or prejudicial action also includes i) all dissemination of ideas based on racial or ethnic superiority or hatred, by whatever means; ii) incitement to hatred, contempt or discrimination against members of a group on grounds of their race, colour, descent, or national or ethnic origin; iii) threats or incitement against persons or groups, iv) expression of insults, ridicule or slander of persons or groups or justification of hatred, contempt or discrimination when it clearly amounts to incitement to hatred or discrimination; (v) participation in organizations and activities which promote and incite racial discrimination. While Nielsen, (2002) argues hate speech is instrument of degradation and humiliation of one's esteem, Parekh (2006) states that it makes victims to become aggressive and dangerous. Indeed, hate speech has continued to be activated as main tool for election in Africa which continues to claim lives during election years and beyond.

Knowing the negative effect hate speech, stop gaps were also mounted through various law enactments noting that hate speech is not free speech (Hylton, 1996) while section 39 (1) of Nigeria 1999 Constitution as amended provides that "every person shall be entitled to freedom of expression..." however section 45 provides that nothing in section 39 shall invalidate any law that is reasonably justifiable in a democratic society in the interest of public order, public morality and for the purpose of protecting the rights and freedom of other persons.

\subsection{The Gap in the Literature}

The literature reviewed did great justice to the narrative on security and social justice.Most writers have continued to address the political implication of hate speech. Hate speech also tend to make group of people feel not wanted even in the same country as exemplified two years ago in Nigeria. Though, none of the literatures addressed the economic angle extensively. This paper sees it as oversight and wishes to address it. When hate speech is perpetrated, violent ensues and people and their economic where withal are disconnected, hunger and economic lull becomes the order of the day. Modest economic gains risk is being reversed as avalanche of hate speechesarethrown into the unsuspecting public. In this vein, the investing public is averse to investment as it watches the scenario of insecurity play out. Investment flourishes in a safe haven. Many hold on to the funds they would have ordinarily invested but for being skeptical and uncertain economic environment.

Congestion and lack of sanitation has put the country last in most surveys a) happiest people on earth b) the most miserable people on earth and c) the hunger capital of the world. Loan from Deposit Money Banks comes in trickles as they weigh the risk of none performing loans and uncertainty that is the lot of unplanned migration. Hate speech aggravates uncalculated risks and increases transport, energy expenditureand drives up inflation in Nigeria.There is no economy that thrives under uncertainty with exchange rate, inflation and complicated monetary policy management. Nigeria cannot be an exemption.

\section{Section Three: Methodology}

\subsection{Research Design}

Research Design is a plan stipulated as a guide to the collection and analysis of data for a study (Baridam, 1995). This helps the researcher to formulate a model with various variables that could help him draw a conclusion from the result he obtained. Method of investigation shall be the use of both primary and secondary data sources. Our mode of primary data shall be the use of survey in order to make our work contemporary.

\subsection{Population of Study, Sources of Data and Sample Size}

The population of this study shall be drawn from the political gladiators and banks management to reflect the impact of hate speech on the economy. While our secondary data shall be sourced from publications and statistical bulletins, questionnaire shall be used for our survey.

Taro Yamane's formula is used to determine the sample size of our population thus:

$$
\mathrm{n}=\frac{\mathrm{N}}{1+\mathrm{N}(\mathrm{e})^{2}}
$$

Where: $\mathrm{n}=$ sample size sought 
$\mathrm{e}=$ level of confidence (0.05)

$\mathrm{N}=$ population size of Bank and Political Gladiators (3000)

Substituting with values:

$\begin{array}{lll}\mathrm{n} & =\frac{3000}{1+3000(0.05)^{2}} & 2.0 \\ \mathrm{n} & =\frac{3000}{1+3000(0.0025)} & 3.0 \\ \mathrm{n} \quad= & \frac{3000}{1+7.5} & 4.0 \\ \mathrm{n} \quad & \frac{3000}{8.5} & 5.0 \\ \text { Sample size: } \mathrm{n} \quad=\quad 353 & 6.0\end{array}$

Section Four: Data Analysis and Interpretation of Result

\subsection{Description of the Sample}

The Author distributed 353 copies of questionnaire were distributed and 300respondents returned the completed questionnaires. This shows 85 percent out of the 353 distributed.

Table 4.1: Allocation of Questionnaire

\begin{tabular}{|l|l|l|l|}
\hline S/No. & Status of Respondents & Questionnaires Distributed & No. Responded \\
\hline a) & Bank officials & 200 & 170 \\
\hline b) & Politicians & 153 & 130 \\
\hline & Total & 353 & 300 \\
\hline
\end{tabular}

Source: Survey, 2018

\subsection{Method of Data Analysis and Presentation}

Data were presented in tables and analyzed using descriptive statistics and simple percentage formula thus:

$\mathrm{F}=\frac{\text { No. of Respondents }}{\mathrm{Y}} \times 100$

Where: $\quad F=$ Frequency

$\mathrm{Y}=$ total population of the study

$100=\%$

Table 4.1: Distribution of Respondents by Status

\begin{tabular}{|l|l|l|}
\hline Respondent Status & No. of Respondents & Percentage (\%) \\
\hline Bank officials & 170 & 56.7 \\
\hline Politicians & 130 & 43.3 \\
\hline Total & 300 & 100 \\
\hline
\end{tabular}

Source: Survey, 2018

From the Table 4.1 above, Bank officials and Politicianswere targeted.

Table 4.2: Respondents Sex Distribution

\begin{tabular}{|l|l|l|}
\hline Sex & No. of Respondents & Percentage (\%) \\
\hline Male Bank officials & 120 & 40.0 \\
\hline Female Bank officials & 50 & 16.7 \\
\hline Male Politicians & 100 & 33.3 \\
\hline Female Politicians & 30 & 10.0 \\
\hline Total & 300 & 100 \\
\hline
\end{tabular}

Source: Survey, 2018

Table 4.2 above shows 40 per cent of the respondents are malebank officials, 16.7 per cent are female bank officials, and 33.3per cent are male politicians while 10 per cent are female politicians. The gender sensitivity was done for spread. 
Table 4.3: Age Distribution of Respondents

\begin{tabular}{|l|l|l|}
\hline Ages & No. of Respondents & Percentage (\%) \\
\hline $35-50$ & 190 & 63.3 \\
\hline $51-70$ & 110 & 36.7 \\
\hline Total & 300 & 100.0 \\
\hline
\end{tabular}

Source: Survey, 2018

Table 4.3 shows the age distribution of the Respondents disaggregated into two showing 63.3 per cent and 36.7 per cent respectively.

Table 4.4: Is Hate Speech the same as Free Speech?

\begin{tabular}{|l|l|l|}
\hline Response & No. of Respondents & Percentage (\%) \\
\hline Yes & 7 & 2.3 \\
\hline No & 293 & 97.7 \\
\hline Total & 300 & 100.0 \\
\hline
\end{tabular}

Source: Survey, 2018

Table 4.4shows Respondents that 2.3 per cent said 'Yes' while 97.7 per cent said 'No' respectively.

Table 4.5 Does Hate Speech affect the economy?

\begin{tabular}{|l|c|c|}
\hline Response & No of Respondents & Percentage (\%) \\
\hline Yes & 283 & 94.3 \\
\hline No & 17 & 5.7 \\
\hline Total & 300 & 100.0 \\
\hline
\end{tabular}

Source: Survey, 2018

The Table 4.5 states that 94.3 per cent believes that hate speech affects the economywhile 5.7 per cent does not.

Table 4.6: Does Hate Speech instigate violence that causes capital flight

\begin{tabular}{|l|l|l|}
\hline Response & No of Respondents & Percentage (\%) \\
\hline Yes & 278 & 92.7 \\
\hline No & 22 & 7.3 \\
\hline Total & 300 & 100.0 \\
\hline
\end{tabular}

Source: Survey, 2018

Table 4.6: 92.7 per cent of Respondents accept that Hate Speech causes capital flightwhile 7.3 per cent believe otherwise.

Table 4.7:Should government clamp down on users of Hate Speech

\begin{tabular}{|l|c|c|}
\hline Response & No. of Respondents & Percentage (\%) \\
\hline Yes & 215 & 71.7 \\
\hline No & 85 & 28.3 \\
\hline Total & 300 & 100.0 \\
\hline
\end{tabular}

Source: Survey, 2018

Table 4.7The table above shows that 71.7 per cent of the respondents indicate that government should clamp down on hate speech users while 28.3 per cent said the government should not.

\subsection{Discussion of Finding}

The study usedbanks staff and some categories of politicians as survey population. This is because the banks notice capital flight as withdrawals or transfers are done are the bankers while the politicians engage in hate speech that tend to heat up the polity. By this, we chose 170 and 130 bankers and politicians respectively such that with our common percentage analysis, it gave us 56.7 and 43.3 per cent respectively. The survey population was also disaggregated into male and female categories for equal representation at 40 and 16.7 per cent respectively for the bankers while 33.3 and 10 per cent respectively are for the male and female politicians. 
Also, age of bankers and politicians were considered in Table 4.3. The following Tables were to ascertain the understanding of the survey group of the difference between hate speech and free speech, and the effect of hate speech on the economy. 94.3 per cent showed that hate speech affects the economy negatively while 57 per cent said that effect is not there on the economy. 71.7 per cent believe that there is capital flight away from hate speech-prone environment.

From our data analysis, there is the significant understanding of the negative effect of hate speech in the economy which translates into capital flight. improvement in freedom of speech and civil liberties were among the immediate gains of Nigeria's transition to civilian rule in 1999. Further findings indicate that hate speech has continued to motivate political violence and downturn in economic growth in Nigeria. Hence moderation of free speech though the enabling laws would put to check freelance in freedom of speech.

Hence, higher percentage of the population infers that politicians are in the habit of using unbridled words that could cause mayhem while they use it in a loose form. Both the economy and the populace suffer the heist that is ignited by hatred through political differences, ethniccolouration, religious and regional divides among the simple-at-heart in the society.

From our research, Nigeria economy has continued to suffer in many ways ranging from migration from the violence infested areas to supposedly safe haven that has not only been invaded by the twin evil of ills that come through congestion to sanitation and epidemic that accompanies such unorganized movement. Some people were able to escape by whiskers while some were not as lucky. Hunger and starvation are now the lot of many while uncountable investments and individual investors cannot say what really hit them. The annexure here is that the result of hate speech is an ill wind that blows no one good. Such is the lot of many Nigerians today as the wind of business closures and retrenchment of workers which hitherto blue-chip could not fathom that they could be part of.

\section{Section Five: Conclusions and Recommendations}

The study has examined the correlation between hate speech and their implication on the Nigeria economy. The result from the survey conducted corroborated the fact that there hate speech is the undoing of any economy, therefore, should not be tolerated under any guise. With the increased interest in politics which many entrants see as a shortcut of escape from the pangs of poverty, cannot but use any trick both in and outside the books, to get to their desired political post. Hence, despite the number of years Nigeria returned to the part of democracy, the citizens have become worse-off while they have continued to be promised Eldorado by the politicians. The politicians also use the common citizens as cannon fodder in their bid to gain power. The outcome of our survey as testified by both the bank officials and the career politicians is worrisome.

Consequently, there is the understanding by the surveyed public that the carnage occasioned by perpetrators of hate speech renege every effort made by both government and private investors. In other to stem the tide of the consequences of hate speech in Nigeria polity and her socio-economic life, there must be concerted effort by all and sundry to insist that those that make the nation vulnerable through these unpatriotic and unguarded utterances must be made to face the full weight of the law, if there is any.

Having harnessed the ills of hate speech, the following recommendations are hereby made:

a) Patriotism should be acted out by all in the country.

b) Utterances by individuals at any fora should be censored not to infringe on the rights of other citizens.

c) There should be political will to diligently prosecute the offenders for conviction.

d) The gullibility of the literate class should not be exploited for political gain.

e) Other means of communication such as social media should be guarded for them not to be used to destabilize the economy.

f) There should be continuous national orientation to assist the populace to understand the ingredients of hate speech in any speech.

g) Hate speech should be seen as so not classifying it according to who is making it.

\section{Reference}

Baridam, D. M. (1995).Research Methods in Administrative Science Campbell, J. (2010) "Electoral violence in Nigeria", Contingency Planning Memorandum, No. 9

Coleman, J. S. (1986) Nigeria: Background to nationalism. Benin City: Broburg and Wistrom

Ekanola, A. B. (2006). National Integration and the Survival of Nigeria in the 21 st Century. The Journal of Social, Political and Economic Studies, Volume 31, Number 3, Fall 2006). 
Hylton K. .N (1996) Implications of Mill's theory of liberty for the regulation of hate speech and hate crimes.Chicago: University of Chicago Law School Roundtable

Kayambazinthu, E. \&Moyo, F (2002) "Hate speech in the new Malawi", in H. Englund (ed.) A democracy of chameleons:politics and culture in the new Malawi. Stockholm: Elanders Gotab

Leets, L. (2002). Experiencing Hate Speech: Perceptions and Responses to Anti-Semitism and Antigay Speech.Journal of Social Issues. Vol. 58

Nemes, I. (2002). Regulating Hate Speech in Cyberspace: Issues of Desirability and Efficacy.Information \& Communications Technology Law.Vol. 11

Neisser, E. (1994) "Hate Speech in the New South Africa: Constitutional consideration for a land recovering from decades of rational repression and violence", South African Journal of Human Rights 10: 33-356

Nielsen, L.B. (2002). Subtle, Pervasive, Harmful: Racist and Sexist Remarks in Public as Hate Speech. Journal of Social Issues, Vol. 58

Parekh, B. (2006). Hate Speech: Is There a Case for Banning? Public Policy Research

Spiegel, L. (1999). Hate Speech, Civil Rights and the Internet: The Jurisdictional and Human Rights Nightmare. Albany Law Journal of Science \& Technology

Witschge,.C. (2008). Examining Online Public Discourse in Context: A Mixed Method Approach.Javahost- the Public, Vol.15, No. 2 